\title{
Sequencing bias: comparison of different protocols of MicroRNA library construction
}

\author{
Geng Tian ${ }^{1,4 \dagger}$, ShangQuang Gan ${ }^{2 \dagger}$, XuYang Yin ${ }^{3,4 \dagger}$, Hong Luo ${ }^{4}$, XiaoHong Xu', Lars Bolund ${ }^{4,5}$, XiuQing Zhang ${ }^{4 *}$ \\ and Ning Li ${ }^{6 *}$
}

After publication of this work [1], we noted that we inadvertently failed to add our collaborators ShangQuang Gan and Ning Li to the complete list of authors.

\begin{abstract}
Acknowledgements
We thank Tian Wei for data analysis, and Søren Nørby for revising the manuscript. This work was supported by a grant from the Ministry of Science and Technology of China(973 program: 2009CB941603,863 program: 2006AA02A301)

\section{Author details}

'Beijing Institute of Genomics, Chinese Academy of Science, Beijing 101300 China. ${ }^{2}$ Key Labs of Sheep Breeding and Reproduce, Xinjiang Academy of Agricultural and Reclamation Science, Shihezi 832000, China. ${ }^{3}$ Genome Research Institute, ShenZhen University Medical School, ShenZhen 518000, China. ${ }^{4}$ Beijing Genomics Institute, Shenzhen 518000, China. Insitute of Human Genetics, University of Aarhus, Aarhus DK-8000, Denmark. ${ }^{6}$ State Key Laboratories for Agrobiotechnology, College of Biological Science, China Agriculture University, Beijing 100193, China.
\end{abstract}

\section{Authors' contributions}

GT participated in the design of the study. SQG selected and prepared the samples. XYY participated in the design of the study, drafted the manuscript, and carried out the GRT-PCR studies. HL and XHX carried out miRNA libraries' construction for cloning and SBS sequencing. XQZ and NL participated in the design of the study. LB participated in the interpretation of data. All authors revised the manuscript and approved the final version to be published.

Received: 6 May 2011 Accepted: 11 May 2011 Published: 11 May 2011

\section{Reference}

1. Tian $G$, Yin XY, Luo H, Xu XH, Bolund L, Zhang XQ: Sequencing bias: comparison of different protocols of MicroRNA library construction. BMC Biotechnology 2010, 10:64.

doi:10.1186/1472-6750-11-48

Cite this article as: Tian et al: Sequencing bias: comparison of different protocols of MicroRNA library construction. BMC Biotechnology 2011 11:48.

\footnotetext{
* Correspondence: zhangxq@genomics.org.cn; ninglbau@public3.bta.net.cn † Contributed equally

${ }^{4}$ Beijing Genomics Institute, Shenzhen 518000, China

${ }^{6}$ State Key Laboratories for Agrobiotechnology, College of Biological Science,

China Agriculture University, Beijing 100193, China

Full list of author information is available at the end of the article
}

Submit your next manuscript to BioMed Central and take full advantage of:

- Convenient online submission

- Thorough peer review

- No space constraints or color figure charges

- Immediate publication on acceptance

- Inclusion in PubMed, CAS, Scopus and Google Scholar

- Research which is freely available for redistribution

Submit your manuscript at www.biomedcentral.com/submit
() Biomed Central
C Biomed Central

(C) 2011 Tian et al; licensee BioMed Central Ltd. This is an Open Access article distributed under the terms of the Creative Commons Attribution License (http://creativecommons.org/licenses/by/2.0), which permits unrestricted use, distribution, and reproduction in any medium, provided the original work is properly cited. 